\title{
Öğretmen Adaylarının Öğretmen Algısı
}

\section{Teacher Candidates' Perceptions About Teacher}

\begin{tabular}{l} 
Anahtar Kelimeler \\
\hline Öğretmen adayı, \\
Meslek, \\
Alg1, \\
Kelime ilişkilendirme \\
testi,
\end{tabular}

\begin{abstract}
Elif ATABEK-YİĞİT ${ }^{1}$ Fatime BALKAN-KIYICI ${ }^{2}$
Özet

Bu çalışmada 177 öğretmen adayının gelecekteki mesleklerine yönelik algılarının belirlenmesi amaçlanmıştır. Bu amaçla tarama yöntemi kullanılarak desenlenen calışmada veriler kelime ilişkilendirme testi (KİT) kullanılarak elde edilmiştir. Verilerin elde edilmesinin ardından cevap kelimelerin frekansları belirlenmiş ve kesme noktası tekniğinden faydalanılarak kavram ağları çizilmiştir. Çalışmanın sonuçlarına göre en fazla farkl cevap kelime okul öncesi ögretmeni adayları tarafindan, en az farkll cevap kelime ise sosyal bilgiler öğretmeni adayları tarafindan verilmiştir. Bu durumda okul öncesi öğretmeni adaylarının mesleklerine yönelik algllarının diğerlerine kıyasla daha fazla yapılanmış olduğu görülmüştür. Öğretmen adaylarının öğrenim görmekte olduklarl bölümlere göre cevap kelimeler incelendiğinde matematik ögretmeni adaylarının ögretmen kavramını en fazla "okul”, "sevgi”, “ögrenci” kavramları ile; okul öncesi ögretmeni adaylarının en fazla "sevgi” kavramı ile; sinıf ögretmeni adaylarının en fazla "öğrenci" kavramı ile; fen bilgisi ögretmen adaylarının en fazla "rehber" kavramı ile ve sosyal bilgiler ögretmeni adaylarının ise en fazla "okul" kavramı ile ilişkilendirdikleri görülmektedir. Tüm öğretmen adaylarının ortak cevap kelimeleri göz önüne alındı̆̆ında mesleklerini gerçekleştirirken kullanacakları materyalleri, beklenti olan kişisel özellikleri ve eşdeğer gördükleri rolleri ifade eden kavramlar belirttikleri söylenebilir. Çalışmanın sonuçlarından hareketle öğretmen adaylarının büyük ölçüde olumlu algıya sahip oldukları düşünülmektedir.
\end{abstract}

\begin{abstract}
In this study, it was aimed to determine the perceptions of a total of 177 teacher candidates who were studying classroom, science, social sciences, early childhood and mathematics teacher departments. Data were gathered through word association test (WAT). After getting data, frequencies of response words were determined and concept maps were drawn. According to the findings of the study, the most different response words were obtained from early childhood teacher candidates while the least different response words were obtained from social sciences teacher candidates. Therefore, it can be said that early childhood teacher candidates have more structured perception about their future career. When response words were examined according to different departments of teacher candidates, it can be said that mathematics teacher candidates related teacher mostly with "school", "affection", and "student", early childhood teacher candidates with "affection", classroom teacher candidates with "student", science teacher candidates with "guide", and social sciences teacher candidates related with "school". As considering the common responses of all teacher candidates, there were words relating to materials, which they would use when performing their careers, relating to personality traits and relating to roles that they see equal. It can also be said that teacher candidates have mostly positive perception about their future career.
\end{abstract}

Key Words

Teacher candidate,

Teaching profession,

Career,

Perception,

Word association test

Atıf için: $\quad$ Atabek-Yiğit, E., \& Balkan-Kıyıcı, F. (2019). Öğretmen Adaylarının Öğretmen Algısı. Muğla For Citation $\quad$ Sitkı Koçman Üniversitesi Ĕ̆itim Fakültesi Dergisi [MSKU Journal of Education], 6(1), 20-39. DOI: $10.21666 /$ muefd.460666

\begin{tabular}{lll}
\hline Received: 17.09 .2018 & Accepted: 27.03.2019 & Published: 01.05.2019
\end{tabular}

\footnotetext{
${ }^{1}$ Sakarya Üniversitesi Eğitim Fakültesi. e-posta: eatabek@sakarya.edu.tr. ORCID: 0000-0001-7792-2204

2 Sakarya Üniversitesi Eğitim Fakültesi. e-posta: fbalkan@ sakarya.edu.tr. ORCID: 0000-0002-4407-8307
} 
Geçmişi neredeyse insanlık tarihi kadar eski olan ve yalnızca öğretmekten ibaret olmayan öğretmenlik mesleği (Celep, 2004), bir toplumun en önemli öğelerinden biri olan eğitim sisteminin de temelini teşkil etmektedir (Demirtaş, Cömert ve Özer, 2011; Singh ve Singh, 2016). Neredeyse tüm kültürlerde "kutsal" bir meslek sayılan öğretmenlik mesleği (Singh ve Singh, 2016) sürekli çalışma, güncel bilgiye sahip olma, sabır, özveri ve fedakârlığı da gerektirir. Meslekte başarılı olabilmek için mesleğini severek yapmak son derece önemlidir. Eğitim-öğretim sürecine dâhil olmuş tüm bireylerin yaşamlarında önemli bir yer tutan "öğretmen" bireyler tarafından çoğu zaman çok olumlu bir figür, yaşamlarında çok önemli bir unsur olarak hatırlanırken bazen de olumsuz örnekler karşımıza çıkabilmektedir. Elbette bunda öğretmenlerin mesleklerini uygularken kullandıkları meslek ve alan bilgisi kadar kişisel özelliklerinin de payı vardır. Aynı zamanda öğretmenlerin davranış ve uygulamaları mesleklerine yönelik tutum ve algıları ile ilişkilidir. Şüphesiz ki bu durum öğretimin başarısını da etkilemektedir (Demirtaş vd. 2011). Böylelikle öğretmenlerin yetiştirdikleri başarılı nesillerin nitelikli bir toplum oluşturacağı açıtır. Bu bağlamda düşünüldüğünde öğretmenlik mesleğinin toplumu etkileme gücüne sahip mesleklerin önemlilerinden biri olduğu söylenebilir (Can, 2010).

İlgili literatürle de tespit edildiği üzere öğretmenliğin bu denli önemli bir meslek olduğu göz önünde bulundurulduğunda öğretmenlerin ve öğretmen adaylarının mesleklerine yönelik algılarının belirlenmesinin önemli olduğu aşikârdır. Çünkü bu algı onların mesleklerini nasıl gerçekleştirdiklerini ve gerçekleştireceklerini ve dolayısıyla nasıl öğrenciler yetiştirdiklerini etkilemekte ve sonuç olarak eğitim sistemi üzerinde bir etkiye sahip olmaktadır. Mesleğine karşı pozitif tutum sergileyen bir öğretmenin pozitif bir öğrenme ortamı oluşturma noktasında etkili olacağ 1 ve negatif tutuma sahip bir öğretmenin de bilgi seviyesi ne olursa olsun öğrencilerinin performansını olumsuz yönde etkileyeceği söylenebilir (Singh ve Singh, 2016). Mesleğe karşı olumlu tutuma sahip olmanın ve mesleki doyumun başarılı bir eğitimin gereklilikleri olduğu Ushadevi (2005)'nin calışmasının sonuçlarında da ifade edilmiştir. Osunde ve Izevbigie (2006) çalışmalarında Nijerya'daki ilkokul öğretmenlerinin mesleklerine karşı tutumlarının özellikle öğretmenlik mesleğinin ekonomik olarak gerektiği yerde olmaması sebebiyle olumsuz olduğunu ve bu durumun da öğretmenlerin düşük düzeyde eğitim vermesinde bir etken olduğunu ifade etmişlerdir.

Literatürde öğretmenlik mesleğine yönelik algı ve tutumların incelendiği bazı çalışmalar mevcuttur. $\mathrm{Bu}$ çalışmaların çoğunluğunda verilerin metafor yoluyla (Saban, Koçbeker ve Saban, 2006; Nikitina ve Furuoka, 2008; Yılmaz, Göçen ve Yılmaz, 2013; Sezgin Nartgün ve Özen, 2015), anket (Gürbüz ve Kışoğlu, 2007), soru formu (Saks, Soosaar ve Ilven, 2016) ve ölçek kullanılarak (Chakraborty ve Mondal, 2014; Çapa ve Çil, 2000; Erdem ve Anılan, 2000; Çiçek Sağlam, 2008; Akkaya, 2009; Doğan ve Çoban, 2009; Can, 2010; Özder, Konedralı ve Zeki, 2010; Üredi, 2010; Demirtaş vd., 2011; Bektaş ve Nalçac1, 2012; Singh ve Singh, 2016; Soibamcha ve Pandey, 2016; Shaheen, Kashif, Daud, ve Tariq, 2017) elde edildiği ifade edilebilir. Ayrıca çalışmaların çoğunluğunda katılımcılar öğretmen adayları (Erdem ve Anılan, 2000; Doğan ve Çoban, 2009; Özder vd., 2010) ve öğretmenler (Osunde ve Izevbigie, 2006; Üredi, 2010; Soibamcha ve Pandey, 2016) iken bazı çalışmalarda da formasyon öğrencilerinin (Can, 2010; Nartgün ve Özen, 2015) öğretmenlik mesleğine yönelik tutumları incelenmiştir.

Yılmaz vd. (2013)'nin çalışmalarına katılan farklı branşlardaki öğretmen adayları öğretmen kavramını açıklamak için en fazla anne-baba, aile, bahçıvan, rehber, 1şı ve çoban metaforlarını kullanmışlardır. Nikitina ve Furuoka (2008) da yaptıkları çalışmada yabancı bir dil öğrenen üniversite öğrencilerinin yabancı dil öğretmeni kavramına yönelik metaforlarını incelemişler ve sonuç itibariyle metaforların cinsiyete bağlı olarak değiştiğini ve en çok kullanılan metaforun "yetiştiren kimse" şeklinde olduğunu ortaya koymuşlardır. Aynı zamanda katılımcıların öğretmen kavramına yönelik olarak "ebeveyn" metaforunu da çoğunlukla kullandıklarına dikkat çekmişlerdir. Nartgün ve Özen (2015) ise pedagojik formasyon öğrencilerinin öğretmen algısını ortaya koymak için gerçekleştirdikleri çalışmalarında katılımcıların ideal öğretmen kavramına ilişkin metaforlarının cinsiyet ve çalışma durumlarına göre değişmekle beraber çoğunlukla "anlayışlı olan", "model olan", ve "başarılı" metaforları çevresinde yoğunlaştığını ifade etmişlerdir. 
Gültekin (2015) tarafından gerçekleştirilen çalışmada ise ilköğretim öğrencilerinin (şu anki ortaokul) ideal öğretmen algıları ortaya konulmaya çalışılmıştır. 355 öğrenciyle gerçekleştirilen çalışmanın bulguları ideal öğretmenin mesleki özellikleri ve kişisel özellikleri olarak iki ana grupta değerlendirilmiştir. Buna göre öğrencilerin ideal öğretmen olarak değerlendirdikleri kişinin kişilik özelliği olarak toleranslı, sabırlı, sakin, saygı duyan ve eleştiriye açık olan özellikleri ilk sıralarda yer alırken, mesleki özellik olarak ise dersi eğlenceli hale getiren, iyi yetişmiş, işini seven, öğrencilerine karşı anlayışlı olan ve sınıfı iyi yöneten özellikleri ön plana çıkmış olarak bulunmuştur. Çapa ve Çil (2000)'in çalışmasında 340 öğretmen adayının öğretmenlik mesleğine yönelik tutumları bir tutum ölçeği kullanılarak araştırılmış ve sonuçlarına göre öğretmen adaylarının öğretmenlik mesleğine yönelik tutum puanlarının cinsiyet ve sınıf düzeyine göre anlamlı bir farklılık gösterdiği ancak üniversite sınavındaki tercih sırasına göre anlamlı bir farklılık göstermediği bulunmuştur. Benzer şekilde Çiçek Sağlam (2008)'ın yaptığı çalışmanın sonuçlarına göre de kadın müzik öğretmeni adayları öğretmenlik mesleğine yönelik olarak erkek müzik öğretmen adaylarından daha olumlu tutuma sahiptir. Akpınar, Yıldız ve Ergin (2006)'in çalışmalarına göre de fen bilgisi öğretmen adaylarının öğretmenlik mesleğine yönelik tutumları sınıf seviyesine göre değişmekte ve üçüncü sınıf öğrencileri en yüksek tutuma sahip bulunmaktadır. Ayrıca bu çalışmanın sonuçlarında da kadın fen bilgisi öğretmen adaylarının öğretmenlik mesleğine erkek adaylardan daha olumlu tutum gösterdikleri belirtilmektedir. Akkaya (2009)'nın çalışmasının sonuçlarına göre kadın Türkçe öğretmeni adaylarının öğretmenlik mesleğine yönelik tutumları erkek adaylardan anlamlı derecede farklılık göstermektedir. Ayrıca öğretmen adaylarının mesleğe yönelik tutumları liseden mezun oldukları bölüm türü ile de ilişkilidir. Verilen bu literatür özetinden de anlaşılabileceği üzere öğretmen adayları ve öğretmenler mesleklerine yönelik olarak çoğunlukla olumlu tutuma sahiptirler ve bu durum cinsiyet, sınıf ve farklı başka değişkenlere bağlı olarak değişebilmektedir.

Bireylerin algı ve tutumlarının incelenmesinde yukarıda verilen literatürde olduğu gibi metaforlar ve ölçekler kullanılabileceği gibi kelime ilişkilendirme testi gibi teknikler de kullanılabilmektedir. Kelime İlişkilendirme Testleri (KITT) bireylerin belli bir kavramla ilgili kavrayış ve algılayışlarının anlaşılması için kullanılabilecek tekniklerden birisidir (Özata-Yücel ve Özkan, 2015). Bu teknikte katılımcılara belli bir kavram verilerek bu kavram ile ilgili akıllarına ilk gelen kelimeyi belli bir süre dahilinde yazmaları istenir. Genellikle bu teknikte aynı kavram için katılımcının on farklı cevap vermesi beklenir ve bunun için anahtar kavramın alt alta on defa yazıldığı bir kağıt verilir. Böylece katılımcının bahsedilen kavramı hangi diğer kelimeler ile ilişkilendirdiği ortaya çıkarılmaya çalışılır. Genellikle işlem için verilen süre 1 dakikadır. Sürenin kısa olması katılımcının çok derinlemesine düşünmeden kavram ile ilgili en güçlü bağlantılarını ortaya koyabilmeyi amaçlamaktadır (Bahar, Johnstone ve Sutcliffe, 1999). Bu teknik farklı araştırmacılar tarafından farklı amaçlar ile kullanılmıştır. Örneğin, Bahar vd. (1999)'nin yapmış oldukları çalışmada üniversite öğrencilerinin temel genetik kavramları hakkındaki bilişsel yapılarını ortaya koymaya çalışmışlar ve veri toplama aracı olarak kelime ilişkilendirme testi kullanmışlardır. KİT bireylerin bilişsel yapılarını ortaya çıkarmakta kullanılabileceği gibi (Bahar vd., 1999; Bahar ve Özatlı, 2003; Kostova ve Radoynovska, 2008; Aydın ve Taşar, 2010; Kurt ve Ekici, 2013; Özata-Yücel ve Özkan, 2015, Atabek-Yiğit, 2106; Atabek-Yiğit, Yılmazlar ve Çetin, 2016), kavram yanılgılarını belirlemede (Ercan, Taşdere ve Ercan, 2010; Özata-Yücel ve Özkan, 2015), kavramsal değişimin değerlendirilmesinde (Hovardas ve Korfiatis, 2006; Nakiboğlu, 2008; Ercan vd., 2010) ve belli bir konu ile ilgili algının belirlenmesinde (Özata-Yücel ve Özkan, 2015; Yiğit ve Atabek-Yiğit, 2016) de kullanılmaktadır. KİT aracılı̆̆ıyla elde edilen verilerin değerlendirilmesinde genellikle anahtar kelime(ler)ye karşıllk verilen cevap kelimelerin sayısı ve frekansı ve ayrıca cevap kelimelerin birbiri ile olan ilişkisi değerlendirilir (Nakiboğlu, 2008). Veri analizinin sonuçları genellikle kavram ağları ile görselleştirilir (Bahar vd., 1999; Özatl1 ve Bahar, 2010).

$\mathrm{Bu}$ çalışmada öğretmen adaylarının öğretmen kavramına yönelik algılarının belirlenmesi hedeflenmektedir. Öğretmenlerin, yetiştirecekleri öğrenciler yoluyla toplumların geleceğini şekillendireceği göz önüne alındığında, öğretmenlik mesleğine yönelik alglarının belirleneceği bu çalışmanın sonuçlarının literatüre katkı sağlayacağı düşünülmektedir. Öğretmen niteliğinin ve eğitim sisteminin başarısının arttırılması için öğretmen adaylarının mesleklerine yönelik olarak olumlu algıya 
sahip olmaları önemlidir. Bu bağlamda durumun tespiti için yapılmış çalışmalara ihtiyaç vardır. $\mathrm{Bu}$ çalışmada öğretmen adaylarının öğretmenlik algılarının ne olduğu ve adayların öğrenim görmekte oldukları bölüme göre farklılaşıp farklılaşmadığ 1 literatürde var olan çalışmalardan farklı olarak Kelime İlişkilendirme testi kullanılarak incelenmiştir.

\section{Yöntem}

Çalışmada öğretmen adaylarının "öğretmenlik" mesleğine yönelik algıları belirlenmek istendiğinden çalışma tarama modelinde betimsel bir çalışmadır. Karasar (2006)'a göre, olayların, objelerin, varlıkların, kurumların, grupların ve çeşitli alanların "ne" olduğunu betimlemeye, açıklamaya çalışan çalışmalar betimsel çalışmalardır.

\section{Katılımcılar}

$\mathrm{Bu}$ çalışmanın katılımcıları bir eğitim fakültesinin son sınıflarında öğrenim görmekte olan 177 öğretmen adayıdır. Katılımcıların 32'si Fen Bilgisi Öğretmenliği ABD'nda, 40'1 Sınıf Öğretmenliği ABD'nda, 37'si Okul Öncesi Öğretmenliği ABD'nda, 36'si İlköğretim Matematik Öğretmenliği ABD'nda ve 32'si Sosyal Bilgiler Öğretmenliği ABD'da öğrenim görmektedir. Çalışmada katılımcı olarak eğitim sisteminin temel eğitim (okul öncesi öğretmenliği ve sınıf öğretmenliği) ve ortaokul (fen bilgisi öğretmenliği, matematik öğretmenliği, sosyal bilgiler öğretmenliği) kademelerinde hizmet verecek öğretmen adayları belirlenmiş ve bunların gelecekteki mesleklerine yönelik algılarının bir farklılık gösterip göstermediği incelenmiştir. Ayrıca çalışmadaki katılımcıların son sınıfta öğrenimlerine devam etmekte olan öğretmen adaylarından seçilmesinin nedeni eğitim öğretim hayatlarının sonlarına doğru gelecekteki meslekleriyle ilgili algılarının belirlenmek istenmesidir.

\section{Veri Toplama Araci}

$\mathrm{Bu}$ çalışmada verilerin toplanması için Kelime İlişkilendirme Testi (KİT) kullanılmıştır. KİT oluşturulurken öğretmen adaylarının meslekleriyle ilgili algıları belirlenmek istendiğinden "öğretmen" anahtar kelime olarak belirlenmiştir. Anahtar kelime bir sayfaya on defa alt alta yazılmış ve her bir kelimenin karşısına katılımcıların cevaplarını yazmaları için boşluklar bırakılmıştır. Anahtar kelimenin alt alta on defa yazılmasının nedeni zincirleme cevap riskini önlemektir. Zincirleme cevap riski katılımcıların her defasında anahtar kelimeyi değil de bir önce vermiş oldukları cevap kelimeyi anahtar kelime gibi düşünerek cevap vermeleri durumunda ortaya çıkmaktadır (Bahar vd., 1999, Nakiboğlu 2008, Kostova ve Radoynovska 2008). Örneğin “yoğunluk" anahtar kelimesi için verilebilecek "özkütle-hacim-uzay-gezegen-dünya-ay" cevapları her defasında anahtar kelimeye tekrar dönülmeyip bir önceki cevap kelimenin anahtar kelime olarak düşünülmesi sebebiyle zincirleme cevap şeklinde kabul edilir ve analiz sırasında değerlendirmeye alınmaz.

\section{Veri Toplama}

Çalışmada kullanılacak KİT'in oluşturulmasının ardından veri toplama sürecine geçilmiştir. Öncelikli olarak katılımcılar çalışma ile ilgili olarak bilgilendirilmiş ve çalışmaya katılma konusunda onayları alınmıştır. Daha sonra KİT ile ilgili bilgi verilmiş ve tekniğin nasıl kullanıldığı anlatılmıştır. Katılımcılara KİT'nde yer alan anahtar kelime ile ilgili olarak akıllarına gelen ilk ifadeyi anahtar kelimenin karşısına yazmalarının isteneceğinden, bunun on kez tekrarlanacağı bir form ile karşılaşacaklarından ve tüm veri toplama işlemi için 1 dakika süre verileceğinden bahsedilmiştir. Katılımcıların tekniği daha iyi anlayabilmeleri ve veri toplama sürecinin daha sağlıklı yürüyebilmesi için araştırmacı tarafından bir örnek anahtar kelime (ağaç) ile tahtada uygulama yapılmıştır. Bunun için araştırmacı örnek anahtar kelime ile ilgili olarak 1 dakika süre boyunca aklına ilk gelenleri tahtaya yazmış ve sürenin sonunda katılımcılar ile beraber incelemiştir. Araştırmacı ayrıca "zincirleme cevap riski"nden de bahsetmiş ve örnek anahtar kelime için bu riski örneklendirerek (ağaç-orman-piknikmangal-köfte) katılımcıların cevaplarını verirken bu hususa dikkat etmeleri gerektiğini belirtmiştir. Tüm bunların amacı katılımcıların tekniğin kullanımını daha iyi anlayabilmesi ve veri toplama için verilecek sürenin (1 dakika) anlamını idrak edebilmesidir. Ardından uygulama gerçekleştirilmiş ve veriler böylece toplanmıştır. 


\section{Verilerin Analizi}

Katılımcılar öğrenim görmekte oldukları bölümlere göre gruplar olacak şekilde veri toplama işlemi gerçekleştirilmiştir. Öncelikle anahtar kelimeye karşı verilen farklı cevap kelimeler listelenmis ve bunların sıklıkları tespit edilmiştir. Böylece cevap kelimeler için bir sıklık tablosu hazırlanmıştır. Bulguların görsel olarak ifade edilebilmesi için kavram ağları çizilmiştir. Kavram ağları çizilirken Bahar vd. (1999) tarafından önerilen kesme noktası tekniği kullanılmıştır. Buna göre bir anahtar kelimeye verilen cevap kelimelerden sıklığı en yüksek olanın 3-5 puan aşağısı kesme noktası olarak belirlenir ve bu kesme noktasında bu sıklığın üzerindeki cevap kelimeler anahtar kelime ile ilişkilendirilir (Bahar vd., 1999, Bahar ve Özat1, 2003). Daha sonra kesme noktası her defasında belli bir miktar aşağıya çekilerek ağa ekleme yapılmaya devam edilir. Bu işlem tüm anahtar kelimelerin ağın üzerinde belirmesine kadar devam ettirilir. Ancak bu calışmada tek anahtar kavram ile çalışıldığından kesme noktası en son 5 olarak belirlenmiş ve sıklığı 5 'in üzerinde olan cevap kelimeler ağa son olarak ilave edilmiştir. Grafikler öğretmen adaylarının öğrenimlerine devam ettikleri her bir bölüm için ayrı ayrı çizilmiş ve değerlendirilmiştir.

\section{Bulgular}

Çalışmada verilerin analizi sonucunda ulaşılan bulgular; katılımcıların öğrenim görmekte oldukları bölümlere göre farklı cevap kelime sayıları, öğrenim görmekte oldukları bölüme göre olan katılımcılar için çizilen grafikler ve tüm katılımcıların ortak cevap kelimeleri şeklinde yapılandırılmıştır.

Katılımcıların "öğretmen" anahtar kelimesine karşılık vermiş oldukları farklı cevap kelimeler ve sıklıkları Ek 1' de gösterilmektedir. Katılımcıların öğrenim görmekte oldukları bölümler dikkate alınarak "öğretmen" anahtar kelimesine karşılık vermiş oldukları farklı cevap kelime sayıları Tablo 1 'de gösterilmektedir.

Tablo 1. Katılımcıların Öğrenim Görmekte Oldukları Bölümlere Göre Farklı Cevap Kelime Sayıları

\begin{tabular}{llc}
\hline Bölüm & & Farklı cevap kelime sayıs \\
\hline İlköğretim Matematik Öğretmenliği & (IMO) & 123 \\
Okul Öncesi Öğretmenliği & (OÖÖ) & 145 \\
Sını Öğretmenliği & (SNÖ) & 138 \\
Fen Bilgisi Öğretmenliği & (FBÖ) & 120 \\
Sosyal Bilgiler Öğretmenliği & (SBÖ) & 106
\end{tabular}

Bir anahtar kelime için verilen farklı cevap kelime sayısı, bireylerin bu anahtar kelimeye ilişkin anlamaları hakkında bir ipucu verebilir. Verilen bir anahtar kelimeye karşıllk verilen cevap kelime sayısının fazla olması bireyin anahtar kelimeyi daha fazla kelimeyle ilişki kurarak daha iyi anlamlandırdığına işaret sayılabilir (Bahar vd., 1999). Tablo 1 incelendiğinde anahtar kelimeye karşılık en fazla farklı cevap kelime sayısının (145 farklı kelime) okul öncesi öğretmenliğinde okuyan öğretmen adayları tarafından verildiği, en az farklı cevap kelime sayısının (106 farklı kelime) ise sosyal bilgiler öğretmenliğinde okuyan öğretmen adayları tarafindan verildiği görülmektedir. Buradan hareketle, okul öncesi öğretmenliğinde okuyan katılımcıların gelecekteki meslekleriyle ilgili olarak algılarının daha yüksek olduğu sonucuna ulaşılabilir.

Katılımcıların anahtar kelimeye vermiş oldukları cevap kelimeler katılımcıların öğrenim görmekte oldukları bölümlere göre sınıflandırılıp kesme noktası tekniği kullanılarak grafikler çizilmiştir. Katılımcıların verdikleri cevap kelime sayiları incelendiğinde ilk kesme noktasının $>25$ olması gerektiğine karar verilmiş her defasında kesme noktası 5 puan esnetilerek grafik çizme işlemi kesme noktası $>5$ olana kadar sürdürülmüştür. Aşağıda farklı bölümlerde öğrenim gören öğretmen adaylarına yönelik grafikler şekiller halinde sunulmuştur.

Şekil 1'den görülebileceği gibi, İlköğretim Matematik Öğretmenliği’nde öğrenim gören katılımcılar "öğretmen" $i$ en fazla $(25 \geq \mathrm{KN} \geq 20)$ "okul", "öğrenci" ve "sevgi" ifadeleri ile çağrıştırmışlardır. Bir başka deyişle katılımcıların 20'den fazlası cevap kelimelerinde "okul”, "öğrenci" ve "sevgi” ifadelerine yer vermiştir. Kesme noktasının iki defa esnetilmesiyle $(15 \geq \mathrm{KN} \geq 10)$ "tahta" ve " anne" ifadeleri ortaya çıkmaktadır. Kesme noktasının $10 \geq \mathrm{KN} \geq 5$ aralığına esnetilmesiyle ise "baba", "bilgi", 
"fedakarlık", “kalem", “kitap”, “müdür”, “rehber", “sınıf”, “sınav”, “saygı” ifadeleri grafiğe eklenmiştir.

Kesme Noktası $\quad$ Grafik
$($ KN)

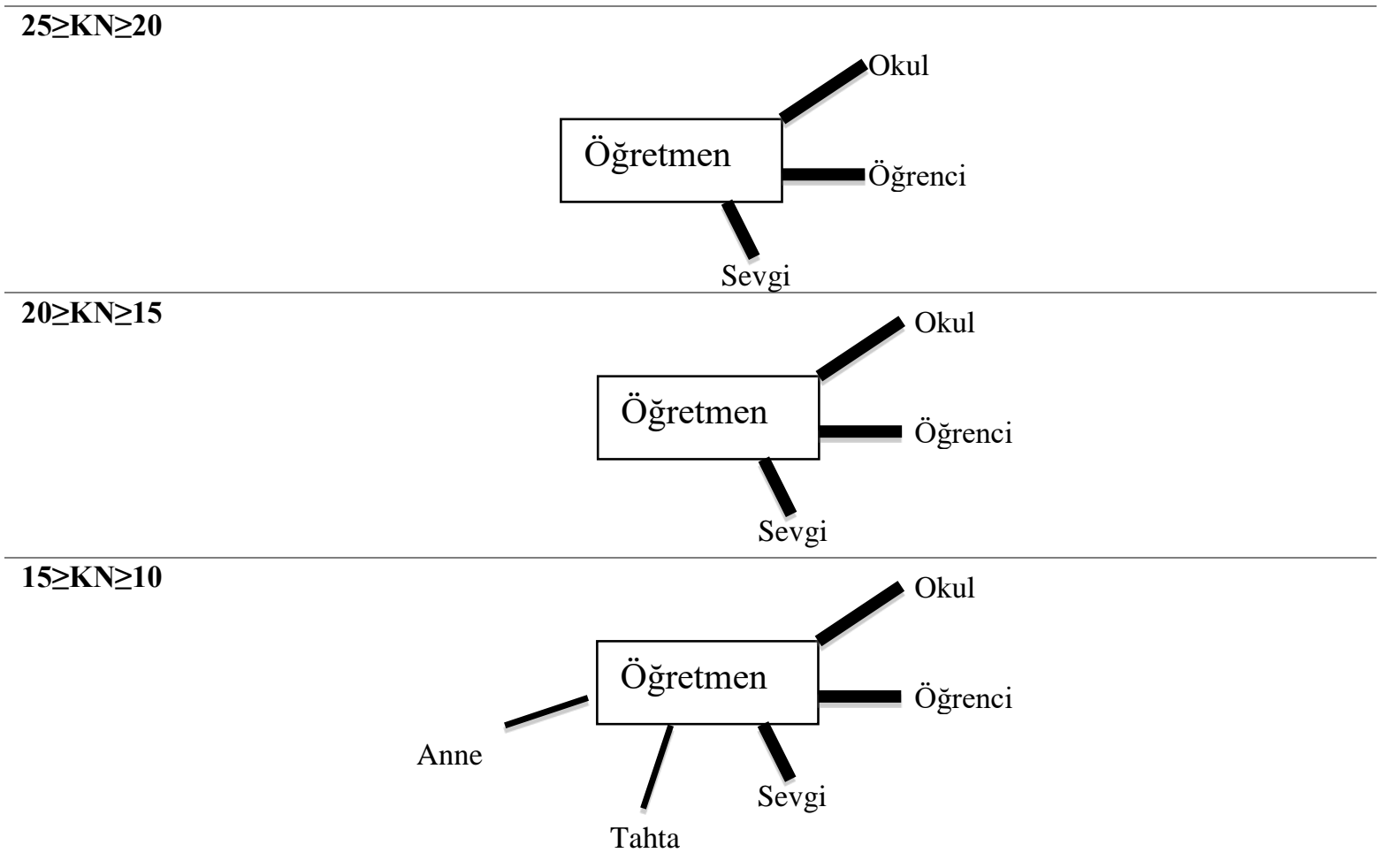

\section{$10 \geq K N \geq 5$}

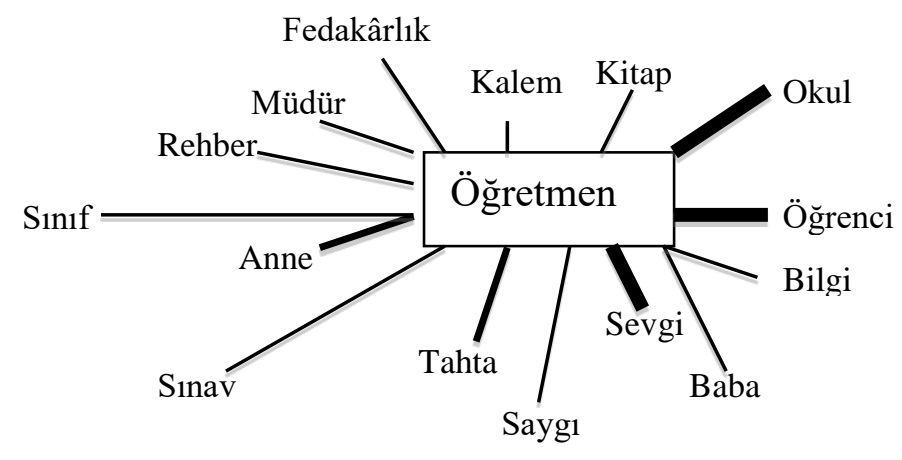

Şekil 1. İlköğretim Matematik Öğretmenliğinde Öğrenim Görmekte Olan Katılımcılara Yönelik Grafik 
Okul Öncesi Öğretmenliği’nde öğrenim görmekte olan katılımcıların verileri ile çizilen Şekil 2 incelendiğinde, bu katılımcıların "öğretmen"i en fazla $(\mathrm{KN} \geq 25)$ "sevgi" ifadesi ile çağrıştırdıkları görülmektedir. Kesme noktasının iki defa esnetilmesiyle $(20 \geq \mathrm{KN} \geq 15)$ "okul" ifadesi de grafiğe eklenmektedir. Kesme noktasının $15 \geq \mathrm{KN} \geq 10$ aralığına esnetilmesiyle "çocuk", "öğretici" ve "saygı" ifadeleri belirmektedir. Kesme noktasının bir kez daha esnetilerek $10 \geq \mathrm{KN} \geq 5$ aralığına getirilmesiyle ise "arkadaş", "anne", "bilgi”, “ders", “eğitim”, güleryüz", "yardımcı", "hayat", "ilgi”, "sınıf”, "öğrenci", "kalem", "sabır", "rehber" ifadeleri yer almaktadır.

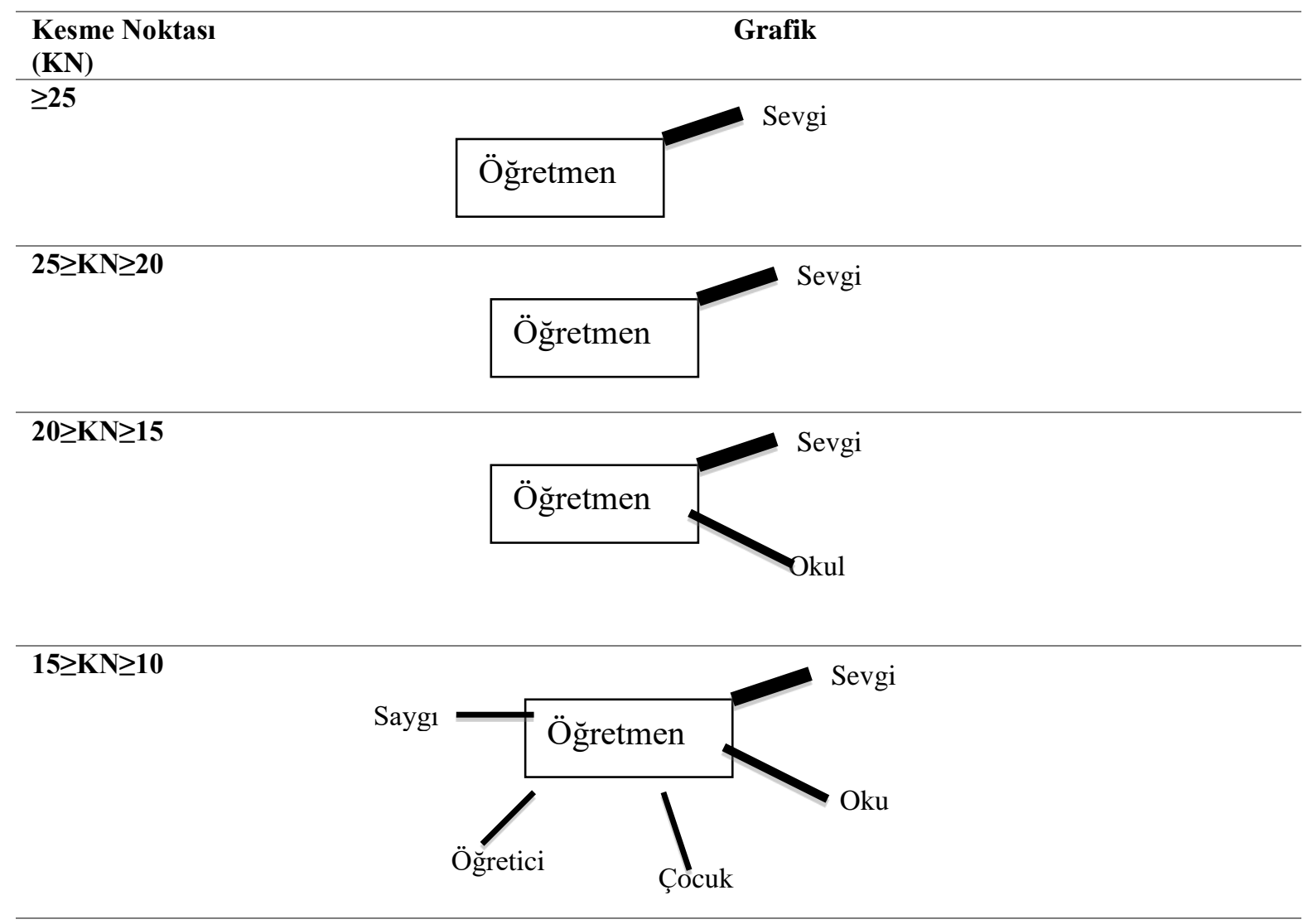

$10 \geq K N \geq 5$

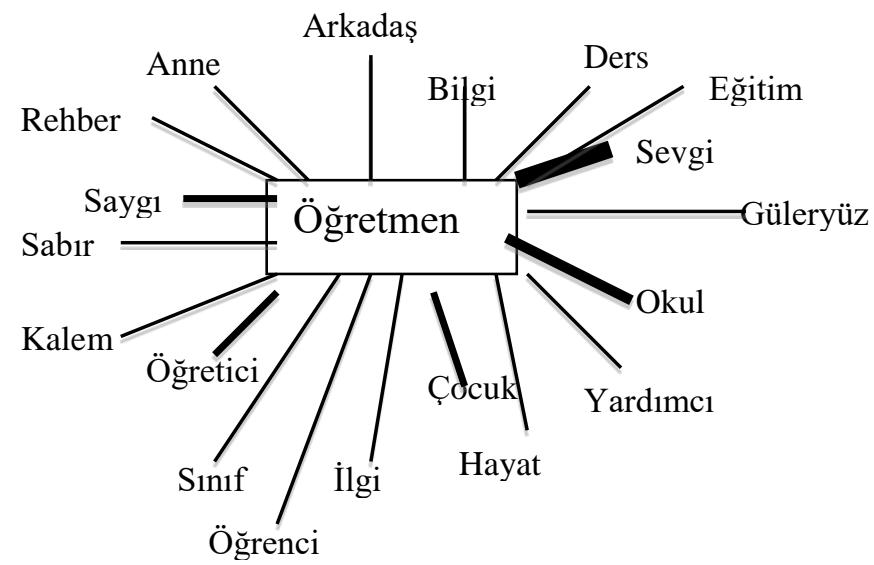

Şekil 2. Okul Öncesi Öğretmenliğinde Öğrenim Görmekte Olan Katılımcılara Yönelik Grafik 
Şekil 3'te de görülebileceği gibi Sınf Öğretmenliğinde öğrenim görmekte olan katılımcılar "öğretmen" $i$ en fazla $(25 \geq \mathrm{KN} \geq 20)$ "öğrenci" ile çağrıştırmışlardır. Kesme noktasının $20 \geq \mathrm{KN} \geq 15$ aralığına getirilmesiyle "okul" ve "sevgi" ifadelerinin de belirdiği görülebilir. Kesme noktasının $15 \geq \mathrm{KN} \geq 10$ aralığına esnetilmesiyle "bilgi", "kitap" ve "sınıf" ifadeleri grafiğe eklenmektedir. Kesme noktasının bir kez daha esnetilerek $10 \geq \mathrm{KN} \geq 5$ aralığına gelmesiyle ise "anne", "disiplin", "eğitim", "emek", "fedakarlık", "kalem", "öğretim", “ders", "çocuk", "tahta”, rehber” ve "saygı" ifadeleri belirmektedir.

\section{Kesme Noktası}

Grafik

(KN)

$\geq 25$

\section{$25 \geq K N \geq 20$}

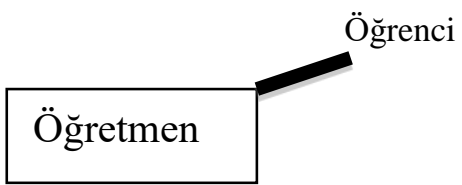

$20 \geq K N \geq 15$

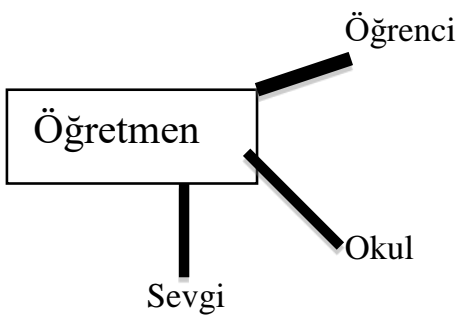

$15 \geq K N \geq 10$

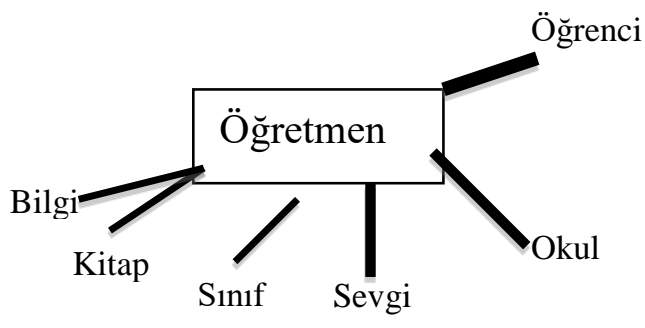

$10 \geq \mathrm{KN} \geq 5$

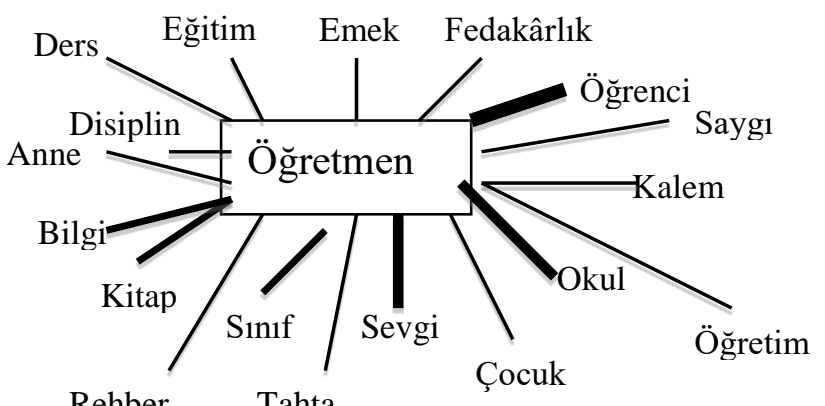

Rehber

Tahta

Şekil 3. Sınıf Öğretmenliğinde Öğrenim Görmekte Olan Katılımcılara Yönelik Grafik 
Fen Bilgisi Öğretmenliğinde öğrenim görmekte olan katılımcılar "öğretmen"i en fazla ( $25 \geq K N \geq 20)$ "rehber" ifadesi ile çağrıştırmışlardır. Kesme noktasının $20 \geq \mathrm{KN} \geq 15$ aralığına esnetilmesiyle "sevgi" ifadesi grafiğe eklenmektedir. Kesme noktasının $15 \geq \mathrm{KN} \geq 10$ aralığına getirilmesiyle "okul" ve "öğrenci" ifadeleri karşımıza çıkmaktadır. Kesme noktasının bir kez daha esnetilerek $10 \geq K N \geq 5$ aralığına getirilmesiyle ise "anne", "bilgi”, “ders”, “disiplin”, “eğitim”, "kitap”, “öğretici”, "öğretim", "saygı" ve "sınav" ifadeleri grafiğe eklenmektedir (Şekil 4).

\begin{tabular}{ll}
\hline Kesme Noktasi & Grafik \\
$(\mathrm{KN})$ &
\end{tabular}

\section{$\mathbf{2 5} \geq \mathbf{K N} \geq \mathbf{2 0}$}

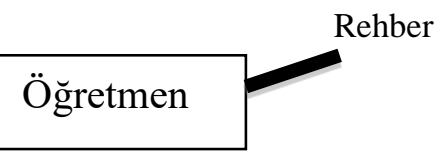

$20 \geq K N \geq 15$

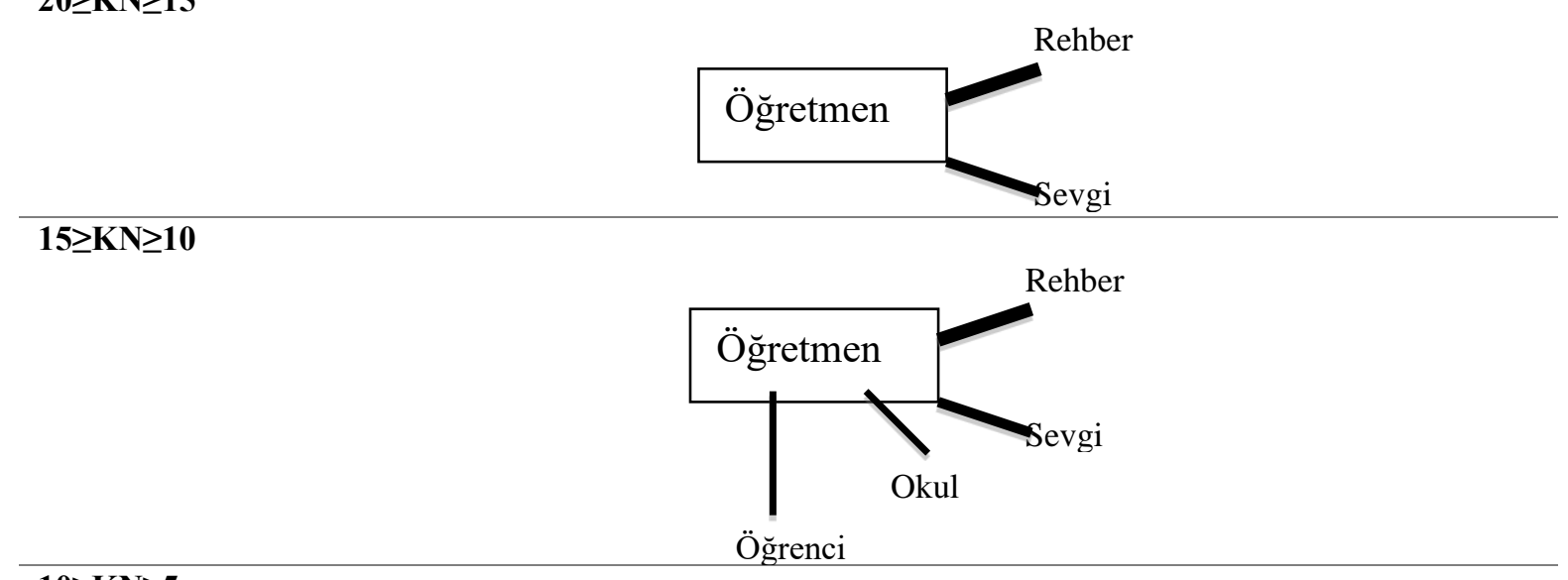

\section{$10 \geq K N \geq 5$}

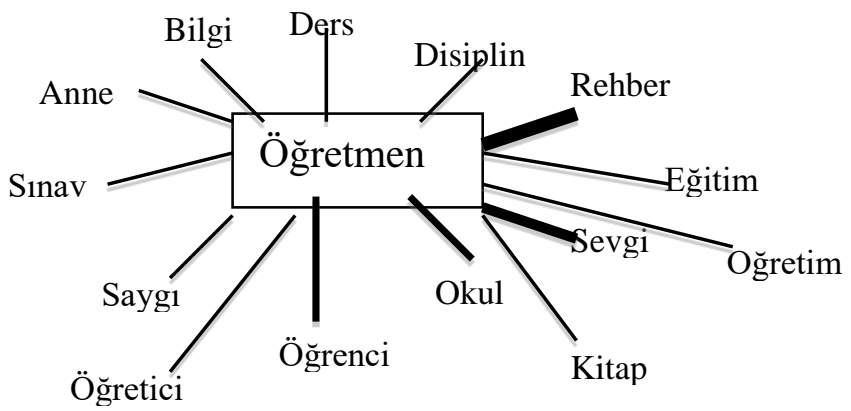

Şekil 4. Fen Bilgisi Öğretmenliğinde Öğrenim Görmekte Olan Katılımcılara Yönelik Grafik 
Şekil 5'den de görülebileceği gibi Sosyal Bilgiler Öğretmenliğinde öğrenim görmekte olan katılımcılar "öğretmen" $i$ en fazla $(25 \geq \mathrm{KN} \geq 20)$ "okul" ifadesi ile çağrıştırmışlardır. Kesme noktasının bir kez esnetilmesiyle $(20 \geq \mathrm{KN} \geq 15)$ "öğrenci" ifadesinin grafige eklendiği görülmektedir. Kesme noktasının $15 \geq \mathrm{KN} \geq 10$ aralığına getirilmesiyle "bilgi", "ders", "eğitim", "kitap", "sinav" ve "sınıf" ifadeleri belirmektedir. Kesme noktasının bir kez daha esnetilerek $10 \geq \mathrm{KN} \geq 5$ aralığına getirilmesiyle ise "gelecek", "kalem”, “müdür”, "not”, “ödev”, “öğretim”, "rehber”, sabır”, “sevgi”, "tahta” ve "tebeşir" ifadeleri grafiğe eklenmektedir.

Kesme Noktası $\quad$ Grafik
$($ KN)

$(\mathrm{KN})$

$\geq 25$

$\mathbf{2 5} \geq \mathrm{KN} \geq \mathbf{2 0}$

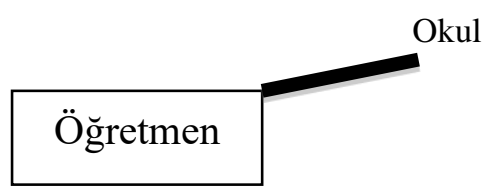

$20 \geq K N \geq 15$

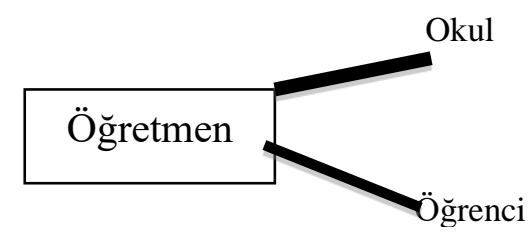

$15 \geq K N \geq 10$

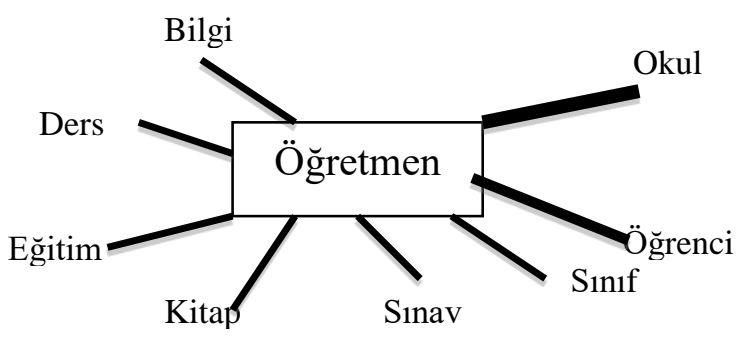

$10 \geq K N \geq 5$

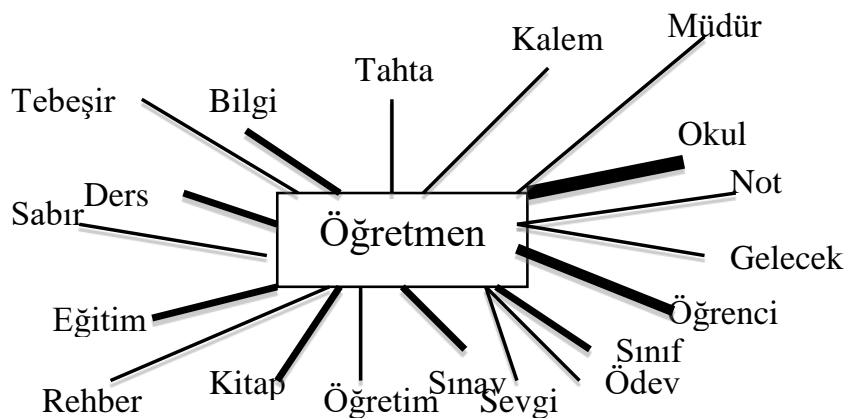

Şekil 5. Sosyal Bilgiler Öğretmenliğinde Öğrenim Görmekte Olan Katılımcılara Yönelik Grafik 
Çalışmanın tüm katılımcılarının (bölüm farkı gözetilmeksizin) “öğretmen” için vermiş oldukları cevap kelimeler içerisinde ortak olanlar Tablo 2'de verilmektedir.

Tablo 2. Tüm Katılımcıların Ortak Cevap Kelimeleri

\begin{tabular}{lll} 
Aile & Hoşgörü & Örnek \\
Anne & Kalem & Rehber \\
Arkadaş & Kitap & Sabır/lı \\
Bilgi & KPSS & Saygı \\
Çiçek & Müdür & Sevgi \\
Ders & Nesil & Sinav \\
Eğitim & Okul & Sinıf \\
Eğitimci & Ödev & Şevkat \\
Emek & Öğrenci & Tahta \\
Hayat & Öğretim & Tebeşir \\
\hline
\end{tabular}

Tablo 2 incelendiğinde tüm katılımcıların ortak cevap kelimelerinde mesleklerini gerçekleştirirken kullanacakları materyaller (kalem, kitap, tebeşir), "öğretmen” kavramının eşdeğeri olarak gördükleri aile, anne, arkadaş, örnek, rehber kelimeler ve onlara göre "öğretmen"in sahip olması beklenen kişisel özellikler (hoşgörü, sabırlı, saygı, sevgi, şefkat) seklinde gruplanabileceği söylenebilir.

\section{Tartışma, Sonuç ve Öneriler}

Öğretmen adaylarının çok yakın gelecekteki meslekleriyle ilgili algılarının belirlenmek istendiği bu çalışmada aynı zamanda farklı anabilim dallarında öğrenim görmekte olma durumunun bu algı üzerinde bir ilişkisinin olup olmadığı da belirlenmeye çalışılmıştır. Çalışmadan elde edilen bulgular incelendiğinde; öncelikle kelime ilişkilendirme testlerinde her bir farklı branş öğretmen adayının öğretmen kavramı için vermiş olduğu ilişkilendirilen kavram sayısının birbirinden farklılık gösterdiği bulunmuştur. İlişkilendirilen kavram sayısının çokluğu kavrama yönelik farkındalık veya anlam vermenin daha güçlü olduğunun göstergesi olabilir (Bahar vd., 1999). Sonuçlara göre diğer branşlardaki öğretmen adaylarına göre, okul öncesi öğretmenliğinde okuyan katılımcıların öğretmenlik mesleğinin daha çok farklı olay, olgu, obje ve durumlarla bağlantılı olma algısına sahip oldukları sonucuna varılabilir.

İlköğretim Matematik Öğretmenliğinde öğrenim gören katılımcılar "öğretmen" kavramını en fazla "okul", "öğrenci", "sevgi” kavramları ile ilişkilendirmiştir. Daha sonra kelime ilişkilendirme testi kesim noktası iki kez esnetildiğinde bu kavramların yanında "anne" ve "tahta" kavramları ile ilişkilendirmeler yaptıkları görülmektedir. İlköğretim matematik öğretmen adaylarının öğretmen algısında çalışılan yer olarak okul ve hitap edilen grup olarak öğrenci ile arada duygusal bir bağ olmasının gerektiğini yansıtan bir sonuç görülmektedir. Bununla birlikte diğer öğretmen adaylarının ilişki kurmadığı sadece bu grupta dile getirilen bir kavram olarak "tahta" kavramına yer verilmiştir. Bunun sebebinin daha çok problem çözme ve işlem yapma içeriğine sahip bir ders olması dolayısıyla da tahtanın sıklıkla kullanılmasından kaynaklandığı düşünülmektedir.

Okul öncesi öğretmenliğinde öğrenim gören katılımcılar "öğretmen” kavramını en fazla "sevgi" kavramı ile ilişkilendirmiştir. Kesme noktasının iki defa esnetilmesiyle sevgi kavramının yanında "okul” kavramının geldiği görülmektedir. Bir kez daha esnetildiğinde ise "çocuk", "öğretici" ve "saygı" kavramları ile ilişkilendirmeler yaptıkları görülmektedir. Öğretmen adaylarının ilişkilendirme yaptığı kavramlar incelendiğinde; öğretmeni olacakları yaş grubunun diğer gruplara kıyasla en küçük yaş grubunu oluşturması sebebiyle bilişsel bazı kazanımlar yanında duyuşsal özelliklerin de ön planda tutulması gerektiğinden bu durumun sonuçlara yansıdığı düşünülmektedir. Sevgi kavramı ile birlikte saygı kavramına da ilişkilendirmelerde yer verildiği görülmektedir. Okul öncesi öğretmen adaylarının öğretmenlik mesleği ile öncelikli olarak ilişkilendirdikleri sevgi kavramı, okul öncesi eğitim programındaki öğretmen rollerinde de yer almaktadır. Programa göre; çocuklar sadece değer 
gördükleri, sevildiklerinden emin oldukları ve kendilerini güvende hissettikleri destekleyici ortamlarda keşfederler ve sunulan öğrenme firsatlarını değerlendirirler (MEB ${ }^{\mathrm{a}}$, 2017).

Sınıf öğretmenliğinde öğrenim gören katılımcılar “öğretmen” kavramını en çok "öğrenci” kavramı ile ilişkilendirmiştir. Daha sonra kelime ilişkilendirme testi kesme noktası bir kez esnetildiğinde öğrenci kavramının yanında "okul" ve "sevgi" kavramları ile ilişkilendirmeler yaptıkları görülmektedir. Sınıf öğretmenliğinde öğrenim gören katılımcıların öğretmenlik mesleğini öncelikli olarak eğitim öğretim sürecinin en önemli öğeleri olan öğrenci ve okul ile ilişkilendirmenin yanında sevgi kavramı ile ilişkilendirmelerinin, öğretmenlik mesleğini yapmak isteme sebepleri ile ilişkili olduğu düşünülmektedir. Çermik, Doğan ve Şahin (2010) tarafından yapılan ve sınıf öğretmenliği öğretmen adayları ile yürütülen çalışmada da; öğretmen adaylarının meslek tercih nedenleri olarak "çocuklara olan sevgim", "öğretmeye karşı olan ilgim ve sevgim" gibi ifadelere yer verdikleri görülmektedir.

Fen bilgisi öğretmenliğinde öğrenim gören katılımcılar "öğretmen" kavramını en çok "rehber" kavramı ile ilişsilendirmiştir. Daha sonra kelime ilişkilendirme testi kesme noktası bir kez esnetildiğinde "sevgi" kavramına yer verildiği görülmektedir. Öğretmen adaylarının ilişkilendirme yaptığı kavramlar incelendiğinde; öğretmeni olacakları dersin öğretim programında tanımlanan öğretmen rolüne öncelikli olarak yer verdikleri görülmektedir. Fen bilimleri dersi öğretim program1 öğretmen rollerini tanımlarken iyi bir rehber olunması gerektiğini ve öğrencilere bir bilim insanı gibi araştırma ve düşünme becerilerinin kazandırılması gerektiğini vurgulamaktadır (MEB $\left.{ }^{\mathrm{b}}, 2017\right) . \mathrm{Bu}$ durumun öğretmen adaylarının algısında rehber olma durumunu ön plana çıkarttığı düşünülmektedir.

Sosyal bilgiler öğretmenliğinde öğrenim gören katılımcılar "öğretmen” kavramını en fazla "okul" kavramı ile ilişkilendirmiştir. Kesme noktasının bir kez esnetilmesiyle "öğrenci" ifadesine yer verildiği görülmektedir. Öğretmen adaylarının ilişkilendirme yaptığı kavramlar incelendiğinde; öğretmenlerin kişisel özellikleri veya duyuşsal alana yönelik özeliklerin yer almadığı görülmektedir. Bu durum sosyal bilgiler öğretmenliği bölümünde öğrenim gören katılımcıların öğrencilerle aralarında duygusal bir bağ kurmaya öncelikli olarak yer vermemesinden kaynaklanmış olabilir. Oysaki sosyal bilgiler öğretim programının amaçları arasında yer alan değerler eğitimine ilişkin içeriğin kazandırılmasında öğretmenin rolü önemlidir. MEB (2018)' e göre; eğitim sistemi sadece akademik açıdan başarılı, belirlenmiş bazı bilgi, beceri ve davranışları kazandıran bir yapı olmayıp, temel değerleri benimsemiş bireyler yetiştirmeyi amaçlamaktadır.

Genel olarak ele alındığında öğretmen adaylarının ilişkilendirmelerinde eğitim öğretim sürecinin öğelerine yer verdikleri görülmektedir. Öğretmenin olduğu yer okul ve okulda olması gereken öğrenciler şeklinde bir bilişsel yapıdan söz edilebilir. Bunun yanında öğretmenin öğrencilerle duygusal bir bağ kurması gerektiğine ilişkin bir algının olduğuna dair bir tablo da söz konusudur. Öğretmen adaylarının zihinlerinde yapılandırdığı öğretmen kavramının hem onların almış olduğu bir eğitimin yansıması hem de gelecekte nasıl bir rolleri olacağının göstergesidir. Katılımcıların ortak cevap kelimeleri incelendiğinde öğretmenlerin sahip olması beklenen mesleki özellikler (bilgi, eğitimci) ve kişilik özellikleri (aile, arkadaş, anne, hoşgörü, örnek, rehber, sabırlı, saygı, sevgi, şefkat) şeklinde gruplara ait kelimeler olduğu dikkat çekmektedir. Bu sonuçlar Gültekin (2015)'in ilköğretim öğrencilerinin ideal öğretmen algısını belirlemeye yönelik çalışmasının sonuçları ile benzerlik göstermektedir. İlköğretim öğrencileri de bu çalışmadaki öğretmen adayları gibi öğretmen algılarında öğretmenin kişisel ve mesleki özelliklerini ön plana çıkarmışlardır. Aynı zamanda Saracaloğlu, Y1lmaz, Çengel, Çöğmen, Karademir ve Kanmaz (2000)'1n da belirttiği gibi öğretmenlik mesleği alan ve meslek bilgisinin yanında hoşgörü, sabır, özveri ve alanıyla ilgili gelişmeleri takip etme özelliklerini de gerektirir. Kadıoğlu-Ateş ve Kadıŏlu (2008) da öğretmen adaylarının ideal öğretmen kavramına yönelik düşüncelerinin belirlenmesine yönelik çalışmasının sonuçlarında ideal öğretmenin sabırlı, hoşgörülü, toleranslı, adil, bilgili, iyi eğitimli olması gibi özelliklere sahip olması gerektiğini ifade etmişlerdir. Benzer şekilde Bektaş ve Nalçacı (2012)'nın çalışmasında olduğu gibi öğretmen adaylarının disiplin, sorumluluk, güven, affedicilik, içtenlik, paylaşım, saygı ve dürüstlük gibi kişisel değerlerin sorgulandığı kişisel değerler ölçeğinden aldıkları puanlar ile mesleklerine yönelik tutum puanları arasında kuvvetli ve pozitif bir ilişkinin bulunmuş olması da öğretmenlik mesleğine yönelik tutumun belirleyicilerinden birinin kişisel özellikler olduğunu doğrular niteliktedir. 
Öğretmen adaylarının mesleklerine yönelik algılarının belirlenmesine yönelik çalışmalar önemlidir çünkü bu çalışmaların bulguları nitelikli öğretmen yetiştirilmesi ve eğitim sisteminin başarısına 1şık tutabilir (Demirtaş vd., 2011). Mesleklerine yönelik olarak negatif algıya sahip olan öğretmen adaylarının eğitim sistemi içerisinde negatif bir unsur oluşturma ihtimali yüksektir (Singh ve Singh, 2016). Oysa ki bu durumun öğretmen yetiştirme programları sürecinde tespit edilmesi ve pozitife doğru çevrilmek için çaba harcanması mümkündür. Bu anlamda öğretmen yetiştirme lisans programları öğretmenlik mesleğine ilişkin farklı bileşenlerle ilgili olarak bir içerik sunacak şekilde zenginleştirilebilir.

Bu çalışmada bir eğitim fakültesinde öğrenim görmekte olan 177 öğretmen adayıyla çalışılmış olması ve veri toplama aracı olarak yalnızca KİT kullanılması bir sınırlılık olarak düşünülebilir. Kelime ilişkilendirme testleri bir olay ya da olguya karşı büyük fotoğrafi belirlemekte oldukça etkin bir teknik olmakla birlikte gelecek çalışmalarda daha derinlemesine veri toplanmasına imkan tanıyacak tekniklerin kullanılması, daha geniş ve farklı çalışma grubuyla çalışılması ve konunun daha derinlemesine araştırılması önerilebilir.

\section{Kaynakça}

Afacan, Ö. (2011). Fen bilgisi öğretmen adaylarının "fen" ve "fen ve teknoloji öğretmeni" kavramlarına yönelik metafor durumları. e-Journal of New World Sciences Academy, 6 (1), $1242-1254$.

Akkaya, N. (2009). Öğretmen adaylarının öğretmenlik mesleğine yönelik tutumlarının bazı değişkenlere göre incelenmesi. Dokuz Eylül Üniversitesi Buca Ĕ̈itim Fakültesi Dergisi, 25, 35-42.

Akpınar, E., Yıldız, E. \& Ergin, O. (2006). Fen bilgisi öğretmen adaylarının öğretmenlik mesleğine yönelik tutumları. Dokuz Eylül Üniversitesi Buca Eğitim Fakültesi Dergisi, 19, 56-62.

Atabek-Yiğit, E. (2016). Investigating cognitive structures in some basic chemistry concepts via word association test. Elementary Education Online, 15(4), 1385-1398.

Atabek-Yiğit, E., Yılmazlar, M. \& Çetin, E. (2016). Investigation of classroom teacher candidates' cognitive structures on some basic science concepts. European Journal of Education Studies, 1(4), 33-57.

Aydın, F. \& Taşar, M.F. (2010). An investigation of pre-service science teachers' cognitive structures and ideas about the nature of technology. Ahi Evran Unv. Kirsehir Edu.Fac.Journal, 11(4), 209-221.

Bahar, M. \& Özatlı, N.S. (2003). Kelime ilişkilendirme yöntemi ile lise 1. sınıf öğrencilerinin canlıların temel bileşenleri konusundaki bilişsel yapılarının araştırılması. Balıkesir Üniversitesi Fen Bilimleri Dergisi, 5(2), 75-85.

Bahar, M., Johnstone, A.H. \& Sutcliffe, R.G. (1999). Investigation of students' cognitive structure in elementary genetics through word association tests. Journal of Biological Education, 33(3),134-141. https://doi.org/10.1080/00219266.1999.9655653

Bektaş, F. \& Nalçac1, A. (2012). The relationship between personal values and attitude towards teaching profession. Educational Sciences: Theory and Practice, 12(2), 1244-1248.

Can, S. (2010). Tezsiz yüksek lisans öğrencilerinin öğretmenlik mesleğine yönelik tutumları, Muğla Üniversitesi Sosyal Bilimler Enstitüsü Dergisi, 24, 13-28.

Celep, C. (2004). Meslek olarak ögretmenlik. Ankara: Anı Yayıncılık.

Chakraborty, A. \& Mondal, B.C. (2014). Attitude of prospective teachers towards teaching profession. American Journal of Social Sciences, 2(6), 120-125.

Çapa, Y. \& Çil, N. (2000). Öğretmen adaylarının öğretmenlik mesleğine ilişkin tutumlarının farklı değişkenler açısından incelenmesi. Hacettepe Üniversitesi Ĕ̆itim Fakültesi Dergisi, 18, 6973.

Çermik, H., Doğan, B. \& Şahin, A. (2010). Sınıf öğretmenliği öğretmen adaylarının öğretmenlik mesleğini tercih sebepleri. Pamukkale Üniversitesi Ë̆itim Fakültesi Dergisi, 28, 201-212.

Çiçek-Sağlam, A. (2008). Müzik öğretmenliği bölümü öğrencilerinin öğretmenlik mesleğine yönelik tutumları. Yüzüncü Yıl Üniversitesi Eğitim Fakültesi Dergisi, 5(1), 59-69. 
Demirtaş, H., Cömert, M. \& Özer, N. (2011). Öğretmen adaylarının özyeterlik inançları ve öğretmenlik mesleğine ilişkin tutumları. Ĕgitim ve Bilim, 36(159), 96-111.

Doğan, T. \& Çoban, A.E. (2009). Eğitim fakültesi öğrencilerinin öğretmenlik mesleğine yönelik tutumları ile kaygı düzeyleri arasındaki ilişkinin incelenmesi. Ĕgitim ve Bilim, 34(153), 157168.

Ercan, F., Taşdere, A. \& Ercan, N. (2010). Kelime ilişkilendirme testi aracılığıyla bilişsel yapının ve kavramsal değişimin gözlenmesi. Türk Fen Ĕ̈t. Dergisi, 7(2), 136-154.

Erdem, A.R. \& Anılan, H.(2000). PAÜ eğitim fakültesi sınıf öğretmenligi öğrencilerinin öğretmenlik mesleğine ilişkin tutumları. Pamukkale Üniversitesi Ĕgitim Fakültesi Dergisi, Özel sayı (IV.Ulusal Sınıf Öğetmenliği Sempozyumu Bildirileri), 7, 144-149.

Gültekin, M. (2015). İlköğretim öğrencilerinin ideal öğretmen algısı, Electronic Turkish Studies, $10(11), 725-756$.

Gürbüz, H. \& Kışoğlu, M. (2007). Tezsiz yüksek lisans programlarına devam eden fen-edebiyat ve eğitim fakültesi öğrencilerinin öğretmenlik mesleğine yönelik tutumları( Atatürk üniversitesi örneği). Erzincan Ĕ̈itim Fakültesi Dergisi, 9(2), 71-83.

Hovardas, T. \& Korfiatis, K.J. (2006). Word associations as a tool for assessing conceptual change in science education. Learning and Instruction, 16, 416-432. https://doi.org/10.1016/j.learninstruc.2006.09.003

Kadıoglu-Ateş, H. \& Kadığlu, S. (2018). Identifying the qualities of an ideal teacher in line with the opinions of teacher candidates, European Journal of Educational Research, 7(1), 103-111.

Karasar, N. (2006). Bilimsel Araştırma Yöntemi (16. Baskı), Ankara: Nobel Yayın Dağıtım.

Kostova, Z. \& Radoynovska, B. (2008). Word association test for studying conceptual structures of teachers and students. Bulgarian Journal of Science and Education Policy, 2(2), 209-231.

Kurt, H. \& Ekici, G. (2013). Biyoloji öğretmen adaylarının bağımsız kelime ilişkilendirme testi ve çizme-yazma tekniğiyle "ozmoz" kavramı konusundaki bilişsel yapılarının belirlenmesi. Turkish Studies, 8(12), 809-829. https://doi.org/10.7827/TurkishStudies.5637

MEB (2017a). Okul Öncesi Eğitimi Programı, Talim Terbiye Kurulu Başkanlığı, Ankara.

MEB (2017b). Fen Bilimleri Dersi Öğretim Programı, Talim Terbiye Kurulu Başkanlığı, Ankara.

MEB (2018). Sosyal Bilgiler Dersi Öğretim Programı, Talim Terbiye Kurulu Başkanlığı, Ankara.

Nakiboğlu, C. (2008). Using word associations for assessing non major science students' knowledge structure before and after general chemistry instruction: in the case of atomic structure. Chemistry Education Research and Practice, 9, 309-322. https://doi.org/10.1039/B818466F

Ocak, G. \& Gündüz, M. (2006). Eğitim fakültesini yeni kazanan öğretmen adaylarının öğretmenlik mesleğine giriş dersini almadan önce ve aldıktan sonra öğretmenlik mesleği hakkındaki metaforlarının karşılaştırılması. Afyon Kocatepe Üniversitesi Sosyal Bilimler Dergisi, 8(2), 293- 310.

Osunde, A.U. \& Izevbiege, T.I. (2006). An assessment of teachers' attitude towards teaching profession in midwestern Nigeria. Education, 126(3), 462-467.

Özata-Yücel, E. \& Özkan, M. (2014). Fen bilimleri öğretmen adaylarının çevre algılarının kelime ilişkilendirme aracılığıyla belirlenmesi. e-International Journal of Educational Research, 5(4), 41-56.

Özata-Yücel, E. \& Özkan, M. (2015). Determination of secondary school students' cognitive structure and misconception in ecological concepts through word association test. Educational Research and Reviews, 10(5), 660-674. https://doi.org/10.5897/ERR2014.2022

Özatlı, N.S. \& Bahar, M. (2010). Öğrencilerin boşaltım sistemi konusundaki bilişsel yapılarının yeni teknikler ile ortaya konması. Abant İzzet Baysal Ünv. Dergisi, 10(2), 9-26.

Özder, H., Konedralı, G. \& Zeki, C.P. (2010). Öğretmen adaylarının öğretmenlik mesleğine yönelik tutumlarının çeşitli değişkenler açısından incelenmesi. Kuram ve Uygulamada Egitim Yönetimi, 16(2), 253-275.

Nikitina, L. \& Furuoka, F. (2008). A language teacher is like ... : Examining Malaysian students' perceptions of language teacher through metaphor analysis. Electronic Journal of Foreign Language Teaching, 5(2), 192-205. 
Saban, A., Koçbeker, B. N. \& Saban, A. (2006). An investigation of the concept of teacher among prospective teachers through metaphor analysis. Educational Sciences: Theory \& Practice, 6(2), 509-522.

Saks, K., Soosaar, R. \& Ilven, H. (2016). The students' perceptions and attitudes to teaching profession, the case of Estonia. 7th International Conferecen on Education and Educational Psychology. Rhodes 11-15 October. Greece.

Saracaloğlu, S., Yılmaz, S., Çengel, M., Çöğmen, S., Karademir, Ç.A \& Kanmaz, A. (2010), Elementary teachers' views about their roles in curriculum development and education process: The case of Denizli. Procedia-Social and Behavioral Sciences, 2(2), 2427-2434.

Sezgin Nartgün, S. \& Özen, R. (2015). Investigating pedagogical formation students' opinions about ideal teacher, teaching profession, curriculum, responsibility, public personnel selection examination (ppse) and employment: A metaphor study. Procedia-Social and Behavioral Sciences, 174, 2674-2683.

Shaheen, F., Kashif, M. F., Daud, H. \& Tariq, M. (2017). Exploring the attitude of prospective teachers towards teaching profession. The Sindh University Journal of Education-SUJE, 45(2), 29-43.

Singh, O.P. \& Singh, S.K. (2016). A study on the attitude of primary school teachers towards teaching profession in Varanasi district of Uttar Pradesh. International Journal of Advanced Research in Management and Social Sciences, 5(8), 119-129.

Soibamcha, E. \& Pandey, N. (2016). Attitude of teachers towards teaching profession. Global Journal of Interdisiplinary Social Sciences, 5(3), 49-51.

Ushadevi, K. (2005). A study of role conflict, job satisfaction and select presage variables discriminating between successful and less successful secondary school women teachers of Kerala (Unpublished PhD). University of Calicut, India.

Üredi, L. (2010). İlköğretim öğretmenlerinin öğretmenlik mesleğine ilişkin algılarının çeşitli değişkenler açısından incelenmesi. e-Journal of New World Science Academy, 5(1), 290-313.

Yılmaz, F., Göçen, S. \& Yılmaz, F. (2013). Öğretmen adaylarının öğretmen kavramına ilişkin algıları: Bir metaforik çalışma. Mersin Üniversitesi Eğitim Fakültesi Dergisi, 9(1), 151-164.

Yiğit, C. \& Atabek-Yiğit, E. (2016). Mechanical engineering students' learning styles and their perception of profession. European Journal of Education Studies, 2(12), 121-137. 
Ek 1. Katılımcıların “öğretmen” anahtar kelimesine karşılık vermiş oldukları farklı cevap kelimeler ve sıklıkları Frekanslar

\begin{tabular}{|c|c|c|c|c|c|}
\hline Cevap kelime & IMO & $\mathrm{OOO}$ & SNO & FBO & SBO \\
\hline 24 Kasım & 1 & & & & \\
\hline Abi & & & & 1 & 1 \\
\hline Abla & 1 & & & 1 & \\
\hline & & & 1 & 2 & \\
\hline
\end{tabular}

\begin{tabular}{|c|c|c|c|c|c|}
\hline & \multicolumn{5}{|c|}{ Frekanslar } \\
\hline Cevap kelime & IMO & $\mathrm{OOO}$ & $\mathrm{SNO}$ & FBO & SBO \\
\hline Birikim & 1 & & & & \\
\hline Biz & & & & & 1 \\
\hline Boncuk & 1 & & & & \\
\hline Bugünü & & & & & 1 \\
\hline
\end{tabular}

\begin{tabular}{|c|c|c|c|c|c|}
\hline Ăgaç & & & 2 & & \\
\hline Aile & 3 & 4 & 1 & 1 & 1 \\
\hline Aktif & & & & 2 & \\
\hline Anlatım & & & & 1 & \\
\hline Anahtar & & & 1 & & \\
\hline Anaokulu & & & 1 & & \\
\hline Ani & & & 1 & & \\
\hline Anlayış & & 2 & & 1 & 1 \\
\hline Anne & 11 & 8 & 8 & 9 & 2 \\
\hline Arkadaş & 1 & 5 & 3 & 3 & 2 \\
\hline
\end{tabular}

değerlendiren

\begin{tabular}{llll}
\hline Çağdaş & 1 & & \\
\hline Çalışkan & 3 & & 1 \\
\hline Çalışa & 1 & 1 & 2 \\
\hline Can damarı & & 1 &
\end{tabular}

Candan 1

\begin{tabular}{llllll}
\hline Cesaret & & & 1 & \\
\hline Cetvel & & & 1 & & \\
\hline Çınar & & 1 & & & \\
\hline Çiçek & 3 & 2 & 1 & 1 & 1 \\
\hline Cilekes & & 1 & & &
\end{tabular}

\begin{tabular}{llllll} 
Ask & & 1 & & & \\
\hline Atanmak & 3 & & 3 & & 1 \\
\hline Atatürk & 3 & 1 & 1 & 1 & \\
\hline Ayakkab1 & & 1 & 2 & 2 & 1 \\
\hline
\end{tabular}

\begin{tabular}{|c|c|c|c|c|c|}
\hline Çocuk & 1 & 14 & 5 & 2 & \\
\hline Çözüm & & & 1 & & \\
\hline Dava & & & 1 & & \\
\hline Davranış & & & & 1 & \\
\hline Dayak & & & 1 & & 1 \\
\hline Dayanak & & 2 & & & \\
\hline
\end{tabular}

\begin{tabular}{ll}
\hline Ayrımcılık & 1 \\
\hline Ayrım & \\
yapmamak & 1
\end{tabular}

\begin{tabular}{|c|c|c|c|c|c|}
\hline Azim & & & 1 & & \\
\hline Baba & 5 & & 4 & 3 & \\
\hline Bağıran & & & & 1 & \\
\hline Baș ağrısı & & & & 2 & \\
\hline Başar1 & 3 & 1 & & 2 & 2 \\
\hline Başöğretmen & 1 & & & & 1 \\
\hline Bayan & & & & 1 & 1 \\
\hline Bayram & & 1 & & & \\
\hline $\begin{array}{l}\text { Beden } \\
\text { eğitimi }\end{array}$ & & & 2 & & \\
\hline
\end{tabular}

Dayanı̧̧ma

\begin{tabular}{|c|c|c|c|c|c|}
\hline Dede & & & 1 & & \\
\hline Defter & 1 & & & 3 & 1 \\
\hline Değerli & 1 & 1 & 1 & & \\
\hline Değer veren & & 3 & & & \\
\hline Delidolu & & 1 & & & \\
\hline Delilik & & & & 1 & \\
\hline Demokratik & & & & 1 & \\
\hline Deney & & & & 1 & \\
\hline Deneyimli & 1 & & 1 & & \\
\hline Deniz & & & 2 & & \\
\hline Ders & 4 & 7 & 9 & 5 & 12 \\
\hline Dershane & 1 & & & & \\
\hline Despot & & 1 & & & \\
\hline Destekçi & & 1 & & & \\
\hline Dinleyen & & & & 1 & \\
\hline Direk & & & & 1 & \\
\hline Disiplin & 2 & 3 & 6 & 6 & \\
\hline
\end{tabular}


Ek 1. Katılımcıların "öğretmen” anahtar kelimesine karşılık vermiş oldukları farklı cevap kelimeler ve sıklıkları (devam)

\begin{tabular}{|c|c|c|c|c|c|}
\hline & \multicolumn{5}{|c|}{ Frekanslar } \\
\hline Cevap kelime & IMO & $\begin{array}{l}\mathrm{OO} \\
\mathrm{O}\end{array}$ & $\begin{array}{l}\text { SN } \\
\mathrm{O}\end{array}$ & FBO & SBO \\
\hline Doktor & & & 1 & & \\
\hline Dost & & & & 1 & \\
\hline Dosya & 1 & & & & \\
\hline Duygusal & & 1 & & & \\
\hline Düşünür & 1 & & & 1 & \\
\hline Düzenli & 1 & 2 & & 1 & \\
\hline Ebeveyn & & & & & 2 \\
\hline Edep & & & & & 1 \\
\hline Eğitim & 4 & 6 & 5 & 7 & 10 \\
\hline Eğitim fak & & & & & 1 \\
\hline Eğitimci & 4 & 4 & 1 & 3 & 4 \\
\hline Eğlence & 1 & 1 & & 2 & \\
\hline Eleştiren & 1 & & & & \\
\hline Emek & 1 & 4 & 5 & 4 & 1 \\
\hline Empati & 1 & & & & \\
\hline En çok seven & & 1 & & & \\
\hline Enerji & & & 1 & & \\
\hline Erdem & & & & & 1 \\
\hline Erkek & & & & 1 & \\
\hline Espri & & & & & 1 \\
\hline Eşit & 1 & 1 & & & \\
\hline Etkinlik & & 1 & 1 & & 3 \\
\hline Ev & 1 & & & & \\
\hline Faranjit & & & 1 & & \\
\hline Fedakar/lik & 5 & 1 & 6 & 4 & \\
\hline Fen & & & & 3 & \\
\hline FF & 1 & & & & \\
\hline Futbol & & & 1 & & \\
\hline Gelecek & 4 & & 1 & 2 & 5 \\
\hline Geliştirme & & 2 & & 2 & \\
\hline Girişimci & & & & & 1 \\
\hline Gökkuşağ1 & & & & 1 & \\
\hline Gurur & & & 1 & & \\
\hline Güleryüz & 1 & 5 & 1 & & 1 \\
\hline Gülümseme & & & 2 & & \\
\hline Güneş & & & 1 & & \\
\hline Gurultu & & & & 1 & \\
\hline Güven & 2 & 4 & 1 & & \\
\hline
\end{tabular}

\begin{tabular}{|c|c|c|c|c|c|}
\hline & \multicolumn{5}{|c|}{ Frekanslar } \\
\hline Cevap kelime & IMO & $\begin{array}{l}\mathrm{OO} \\
\mathrm{O}\end{array}$ & $\begin{array}{l}\mathrm{SN} \\
\mathrm{O}\end{array}$ & FBO & SBO \\
\hline Güzellik & 1 & 1 & & & \\
\hline Güzel giyinen & & & & 1 & \\
\hline Güzel konuşma & & & & 1 & \\
\hline Harf & & & & & 2 \\
\hline Harita & & & & & 1 \\
\hline Hayaller & & & 2 & & \\
\hline Hayat & 1 & 6 & 4 & 1 & 1 \\
\hline Hazır bulunuşluk & & & & & 1 \\
\hline Hedefler & & & & 1 & \\
\hline Hemşire & & 1 & & & \\
\hline Hendek & & & & & 1 \\
\hline Her şey & & & & 1 & \\
\hline Heyecan & & 1 & 1 & & \\
\hline Hikaye & & & & & 1 \\
\hline Hoşgörü & 1 & 4 & 2 & 2 & 2 \\
\hline Huysuz & & & & 1 & \\
\hline Huzur & & 2 & 1 & & \\
\hline Hz.Muhammed & 1 & & & & 1 \\
\hline Işık & & 2 & 2 & & 1 \\
\hline İçten & & 1 & & 1 & \\
\hline İdare & 1 & & & & \\
\hline İdeal & 1 & & & & \\
\hline İdealist & & & & 1 & \\
\hline İdol & 1 & 1 & 1 & & \\
\hline İdrak & 1 & & & & \\
\hline İlaç & & & 1 & & \\
\hline İlerlemecilik & & & & 1 & \\
\hline İletişim & & 1 & & & \\
\hline İlgi & 2 & 5 & 3 & & 2 \\
\hline İlkbahar & & & & 1 & \\
\hline İlkeli & & & 1 & & \\
\hline İlköğretim & & & 1 & & \\
\hline İnsan & & & & & 1 \\
\hline İnsanc1l & & 2 & & 1 & \\
\hline İstek & & 1 & & & \\
\hline İstidat & & & 1 & & \\
\hline İşbirlikçi & & 1 & & & \\
\hline İyi & & & & & 1 \\
\hline
\end{tabular}


Ek 1. Katılımcıların “öğretmen” anahtar kelimesine karşılık vermiş oldukları farklı cevap kelimeler ve sıklıkları (devam)

\begin{tabular}{|c|c|c|c|c|c|}
\hline & \multicolumn{5}{|c|}{ Frekanslar } \\
\hline Cevap kelime & IMO & $\mathrm{OOO}$ & SNO & FBO & SBO \\
\hline İyi niyet & & 1 & & & \\
\hline İz bırakıcı & & 1 & & & \\
\hline Kadın & 1 & 1 & & & \\
\hline Kafa adam & 1 & & & & \\
\hline Kâğgtt & & 2 & & & \\
\hline Kalem & 9 & 5 & 9 & 3 & 9 \\
\hline Kalite & 1 & & & & \\
\hline Kalp & & 1 & & & \\
\hline Karar & & 1 & & & \\
\hline Kariyer & & & & 1 & \\
\hline Karne & 1 & 1 & 1 & & 1 \\
\hline Karşılık & & 1 & & & \\
\hline $\begin{array}{l}\text { Karşılik } \\
\text { beklememek }\end{array}$ & 1 & & & & \\
\hline Kavga & 1 & 1 & & & \\
\hline Kaynak & & & & 1 & \\
\hline Kelime & & & & & 1 \\
\hline Kitap & 6 & 4 & 10 & 5 & 13 \\
\hline Kizgin & & & & 1 & \\
\hline KPSS & 2 & 1 & 4 & 4 & 4 \\
\hline Koruyan & & 1 & & & \\
\hline Koşuşturma & & & 1 & & \\
\hline Koy & & & 2 & 1 & \\
\hline Kravat & & & & 1 & 1 \\
\hline Kurallar & & 1 & & 2 & \\
\hline Kurtaricı & & 1 & & & \\
\hline Kutsal & & 1 & 1 & 1 & \\
\hline Kültürlü & & 1 & & & 1 \\
\hline Kütüphane & & & 2 & & 1 \\
\hline $\begin{array}{l}\text { Latin } \\
\text { alfabesi }\end{array}$ & 1 & & & & \\
\hline Lider & 1 & & 1 & 2 & \\
\hline $\begin{array}{l}\text { Lise } \\
\text { öğretmeni }\end{array}$ & & 1 & & & \\
\hline Maaş & & & 2 & 2 & 1 \\
\hline $\begin{array}{l}\text { Mahmut } \\
\text { hoca }\end{array}$ & & & & & 1 \\
\hline Mantıklı & & 1 & & & \\
\hline Marş & 2 & & & & 1 \\
\hline Masa & & & 2 & & \\
\hline
\end{tabular}

\begin{tabular}{|c|c|c|c|c|c|}
\hline & \multicolumn{5}{|c|}{ Frekanslar } \\
\hline Cevap kelime & IMO & $\mathrm{OOO}$ & SNO & FBO & SBO \\
\hline Masumiyet & & 2 & & & \\
\hline Matematik & 4 & 1 & & 1 & \\
\hline Materyal & 3 & & 3 & & \\
\hline MEB & & & & & 1 \\
\hline Memur & & & & 1 & 3 \\
\hline Meraklı & & 1 & & & \\
\hline Merhametli & 1 & 1 & 1 & 2 & \\
\hline Meslek & 3 & 4 & 3 & 2 & \\
\hline Milli eğitim & 1 & & & & \\
\hline Model & 3 & 1 & 1 & & \\
\hline Muhabbet & 2 & & 1 & & \\
\hline Mum & & & 1 & 1 & \\
\hline Mutluluk & & 4 & 4 & 1 & 1 \\
\hline Müderris & 1 & & & & \\
\hline Müdür & 5 & 1 & 2 & 1 & 5 \\
\hline Müfredat & 1 & & & & \\
\hline Müzik & & 1 & & & \\
\hline Nazik & & 1 & & & \\
\hline Nesil & 2 & 1 & 1 & 1 & 1 \\
\hline Neşe & & 1 & & 1 & \\
\hline Not & 2 & & 1 & & 5 \\
\hline Oksijen & & & 1 & & \\
\hline Okul & 20 & 15 & 19 & 11 & 22 \\
\hline Okumak & & 2 & & & \\
\hline Okuyan & 1 & & & & \\
\hline $\begin{array}{l}\text { Olmak } \\
\text { istediğim }\end{array}$ & & 1 & & & \\
\hline $\begin{array}{l}\text { Olmazsa } \\
\text { olmaz }\end{array}$ & & & 1 & & \\
\hline Oyun & & 2 & & & \\
\hline Ödev & 2 & 2 & 2 & 2 & 5 \\
\hline Öğrenci & 22 & 9 & 22 & 14 & 19 \\
\hline Öğrenmek & & 3 & 4 & & \\
\hline $\begin{array}{l}\text { Öğrenci } \\
\text { seven }\end{array}$ & 1 & & & & \\
\hline Öğretici & 4 & 10 & & 6 & 4 \\
\hline Öğretim & 2 & 2 & 8 & 7 & 9 \\
\hline Öğretmenevi & 1 & & & & \\
\hline $\begin{array}{l}\text { Öğretmenler } \\
\text { günü }\end{array}$ & & & & 2 & \\
\hline
\end{tabular}


Ek 1. Katılımcıların "öğretmen” anahtar kelimesine karşılık vermiş oldukları farklı cevap kelimeler ve sıklıkları (devam)

\begin{tabular}{|c|c|c|c|c|c|}
\hline & \multicolumn{5}{|c|}{ Frekanslar } \\
\hline Cevap kelime & IMO & $\mathrm{OOO}$ & $\mathrm{SNO}$ & FBO & SBO \\
\hline $\begin{array}{l}\text { Öğretmen } \\
\text { masas1 }\end{array}$ & 1 & & & & \\
\hline $\begin{array}{l}\text { Öğretmenler } \\
\text { odas1 }\end{array}$ & 2 & & 2 & 1 & 2 \\
\hline Öğüt & & & 1 & & 1 \\
\hline Onluk & & 1 & 2 & & 4 \\
\hline Onur belgesi & & & & & 1 \\
\hline Örnek & 2 & 4 & 1 & 3 & 1 \\
\hline Otorite & & & & & 1 \\
\hline $\begin{array}{l}\text { Öz } \\
\text { düzenleme }\end{array}$ & & 1 & & & \\
\hline Özgür & & & 1 & & \\
\hline Özgüven & & 1 & & 1 & \\
\hline Özlem & & 1 & & & \\
\hline Özveri & & 2 & & & \\
\hline Para & 1 & & & & \\
\hline Paylaşım & & & 1 & & 1 \\
\hline $\begin{array}{l}\text { Pedagojik } \\
\text { formasyon }\end{array}$ & 1 & & & & \\
\hline Pekiştirec & 1 & & & & \\
\hline Plan & & 1 & 1 & & \\
\hline Pozitiflik & & 1 & & & \\
\hline Problem & & & & & 1 \\
\hline Psikolog & & 1 & & & \\
\hline Radikal & & & & 1 & \\
\hline Rehber & 5 & 8 & 9 & 24 & 7 \\
\hline Sabah & & & & & 1 \\
\hline Sabır/l1 & 2 & 5 & 4 & 3 & 5 \\
\hline Sadakat & 1 & & 1 & & \\
\hline Sadiye hoca & & 1 & & & \\
\hline Samimiyet & 1 & & 1 & & \\
\hline Sanat & & 1 & & 1 & \\
\hline Sari & & 1 & & & \\
\hline Sayg1 & 7 & 11 & 5 & 7 & 3 \\
\hline Saygınlık & & 2 & & & \\
\hline Sebat & & 2 & & & \\
\hline Seçenek & & 1 & & & \\
\hline $\begin{array}{l}\text { Sendikal } \\
\text { haklar }\end{array}$ & & & 1 & & \\
\hline
\end{tabular}

\begin{tabular}{|c|c|c|c|c|c|}
\hline & \multicolumn{5}{|c|}{ Frekanslar } \\
\hline Cevap kelime & IMO & $\mathrm{OOO}$ & SNO & FBO & SBO \\
\hline & & 4 & 1 & 1 & \\
\hline Sevecen & 3 & & & & \\
\hline & & 26 & 15 & 16 & 9 \\
\hline Sevgi & 20 & & & & \\
\hline Sevinç & & & 1 & & \\
\hline Sevimli & 1 & & & 1 & \\
\hline Sicakkanlı & & & & & 1 \\
\hline Sicakl1k & & 2 & & & \\
\hline Siğınak & & 2 & & & \\
\hline & & 3 & 3 & 8 & 13 \\
\hline Sinav & 8 & & & & \\
\hline Sinıf & 7 & 9 & 12 & 4 & 10 \\
\hline Sinıf defteri & & & & 1 & \\
\hline Sinir & & & & 1 & \\
\hline Sira & & 1 & 1 & 1 & \\
\hline Sırdaş & 1 & & 1 & & \\
\hline Silgi & 1 & & 1 & & 1 \\
\hline Sinirli & 1 & & & & \\
\hline Soba & & & 1 & & \\
\hline Sokrates & & 1 & & & \\
\hline Sorgulayan & 1 & 1 & & 1 & \\
\hline Soru & & 1 & & 1 & 1 \\
\hline Sorumluluk & 1 & 1 & 2 & & \\
\hline Sosyal & & & & & 2 \\
\hline Sözlü & 3 & & & & \\
\hline Staj & & & & 1 & 1 \\
\hline Statü & & & 1 & & 1 \\
\hline Stres & 1 & & & & \\
\hline Şefkat & 3 & 3 & 4 & 3 & 4 \\
\hline Tahta & 10 & 1 & 5 & 2 & 7 \\
\hline Tahta kalemi & 1 & & & & \\
\hline $\begin{array}{l}\text { Takdir } \\
\text { belgesi }\end{array}$ & & & & & 1 \\
\hline Takım elbise & & & 2 & 2 & 1 \\
\hline Tarih & & & & & 1 \\
\hline Tatil & & & 2 & & \\
\hline Tatli & & 1 & & & \\
\hline Tebeșir & 1 & 1 & 4 & 1 & 5 \\
\hline
\end{tabular}


Ek 1. Katılımcıların “öğretmen” anahtar kelimesine karşılık vermiş oldukları farklı cevap kelimeler ve sıklıkları (devam)

\begin{tabular}{|c|c|c|c|c|c|}
\hline & \multicolumn{5}{|c|}{ Frekanslar } \\
\hline Cevap kelime & IMO & $\mathrm{OOO}$ & SNO & FBO & SBO \\
\hline Tecrübe & & & & & 1 \\
\hline Temiz & 1 & & & & \\
\hline Temizlikçi & & & 1 & & \\
\hline Teorik & & & 1 & & \\
\hline $\begin{array}{l}\text { Teşekkür } \\
\text { belgesi }\end{array}$ & & & & & 1 \\
\hline Teslimiyet & & & 1 & & \\
\hline Tirnak kontrolü & 1 & & & & \\
\hline Toplant1 & & & & 1 & 1 \\
\hline Toplum & 1 & & & & \\
\hline Tost-ayran & & & 1 & & \\
\hline Umut & 1 & & 1 & & \\
\hline Üniversite & & 1 & 1 & 1 & \\
\hline Uyum & & & 1 & 1 & \\
\hline Var olmak & & 1 & & & \\
\hline Veli & 4 & & 2 & 2 & 1 \\
\hline Veli ziyareti & & & & & 1 \\
\hline Verim & & & 1 & & \\
\hline Yanlış & & & & 1 & \\
\hline Yapılandırmacı & 1 & & & 4 & 1 \\
\hline Yarar & & 1 & & & \\
\hline Yardımcı & & 6 & 1 & & \\
\hline Yardımsever & & 1 & 1 & 3 & 2 \\
\hline
\end{tabular}

\begin{tabular}{|c|c|c|c|c|c|}
\hline & \multicolumn{5}{|c|}{ Frekanslar } \\
\hline $\begin{array}{l}\text { Cevap } \\
\text { kelime }\end{array}$ & IMO & $\mathrm{OOO}$ & SNO & FBO & SBO \\
\hline Yasamak & & 1 & & & \\
\hline Yaslanma & & 1 & & & \\
\hline Yazı & & & & 2 & \\
\hline Yaz1lı & 3 & 1 & & & \\
\hline Yenilik & & 1 & 1 & & \\
\hline Yetenek & 2 & & 1 & 1 & \\
\hline Yeterlilik & & 1 & 1 & 1 & \\
\hline Yetiştirmek & 1 & 1 & & & 1 \\
\hline Yetkin & & 1 & & & \\
\hline Yoklama & & & 2 & & 1 \\
\hline Yorgunluk & & & 2 & 1 & \\
\hline Yon & & & 2 & 1 & \\
\hline Yönetici & 2 & 1 & & & \\
\hline Yöntem & & & 2 & & \\
\hline Yuva & 2 & 2 & & & \\
\hline $\begin{array}{l}\text { Yürüyen } \\
\text { kitap }\end{array}$ & & & & & 1 \\
\hline Zaman & & & & 1 & \\
\hline Zeka & 2 & & & & \\
\hline Zeki & & & 1 & & 1 \\
\hline Zil & & 1 & 1 & & \\
\hline Zorluk & & 2 & 2 & & \\
\hline
\end{tabular}

